\title{
Article
}

\section{Securing Land Rights for All through Fit-for-Purpose Land Administration Approach: The Case of Nepal}

\author{
Uma Shankar Panday ${ }^{1, *(1)}$, Raja Ram Chhatkuli ${ }^{2}$, Janak Raj Joshi ${ }^{3}$, Jagat Deuja ${ }^{4,5}$, Danilo Antonio ${ }^{6}$ \\ and Stig Enemark ${ }^{7}$ \\ 1 Department of Geomatics Engineering, Kathmandu University, Dhulikhel 45200, Nepal \\ UN-Habitat, P.O. Box 107, Kathmandu 44600, Nepal; rr.chhatkuli@unhabitat.org.np \\ 3 Ministry of Land Management, Cooperatives and Poverty Alleviation, Kathmandu 44600, Nepal; \\ janakraj.joshi@nepal.gov.np \\ 4 Community Self Reliance Centre (CSRC), Kathmandu 44700, Nepal; deujaj@csrcnepal.org \\ 5 Land Issues Resolving Commission (LIRC), Kathmandu 44620, Nepal \\ 6 UN-Habitat/LHSS, P.O. Box 30030, Nairobi 00100, Kenya; danilo.antonio@un.org \\ 7 Department of Planning, The Technical Faculty of IT and Design, Aalborg University, 9000 Aalborg, \\ Denmark; enemark@plan.aau.dk \\ * Correspondence: uspanday@ku.edu.np; Tel.: +977-11-415100
}

check for updates

Citation: Panday, U.S.; Chhatkuli, R.R.; Joshi, J.R.; Deuja, J.; Antonio, D.; Enemark, S. Securing Land Rights for All through Fit-for-Purpose Land Administration Approach: The Case of Nepal. Land 2021, 10, 744. https:// doi.org/10.3390/land10070744

Academic Editor: Volker Beckmann

Received: 7 March 2021

Accepted: 13 July 2021

Published: 16 July 2021

Publisher's Note: MDPI stays neutral with regard to jurisdictional claims in published maps and institutional affiliations.

Copyright: (c) 2021 by the authors. Licensee MDPI, Basel, Switzerland. This article is an open access article distributed under the terms and conditions of the Creative Commons Attribution (CC BY) license (https:// creativecommons.org/licenses/by/ $4.0 /)$.

\begin{abstract}
After the political change in Nepal of 1951, leapfrog land policy improvements have been recorded, however, the land reform initiatives have been short of full success. Despite a land administration system based on cadaster and land registries in place, $25 \%$ of the arable land with an estimated 10 million spatial units on the ground are informally occupied and are off-register. Recently, a strong political will has emerged to ensure land rights for all. Providing tenure security to all these occupants using the conventional surveying and land administration approach demands a large amount of skilled human resources, a long timeframe and a huge budget. To assess the suitability of the fit-for-purpose land administration (FFPLA) approach for nationwide mapping and registration of informality in the Nepalese context, the identification, verification and recordation (IVR) of the people-to-land relationship was conducted through two pilot studies using a participatory approach covering around 1500 and 3400 parcels, respectively, in an urban and a rural setting. The pilot studies were based on the FFPLA National Strategy and utilized satellite imageries and smartphones for identification and verification of land boundaries. Data collection to verification tasks were completed within seven months in the urban settlements and for an average cost of 7.5 USD per parcel; within the rural setting, the pilot study was also completed within 7 months and for an average cost of just over 3 USD per parcel. The studies also informed the discussions on building the legislative and institutional frameworks, which are now in place. With locally trained 'grassroots surveyors', the studies have provided a promising alternative to the conventional surveying technologies by providing a fast, inexpensive and acceptable solution. The tested approach may fulfill the commitment to resolve the countrywide mapping of informality. The use of consistent data model and mapping standards are recommended.
\end{abstract}

Keywords: tenure security; land tenure; land policy; fit-for-purpose land administration; pilot study

\section{Introduction}

The land tenure system in Nepal has a history of orientation to feudal landlordism. Historically, until the political change of 1951 when the country was turned into a democratic set-up, most of the fertile land of the state was granted by the aristocratic rulers to various elites who turned to be landlords. Peasants, the real tillers on land, were left behind with limited access and poorly recognized tenure rights on the land they operate. Even today, a large proportion of the arable land is unregistered in the national record [1-3]. Several areas and settlements cultivated for decades are officially unrecognized and undocumented. The rights and legal ownership of the occupants being unrecognized, land 
transactions are often conducted in the informal market and the state is losing large revenue that could have been collected as land taxation and registration fees when land tenure is formally recognized. More alarmingly, being legally unrecognized despite decades of use, the poor landless slum dwellers and peasants in the informal settlements who come generally from different socio-economically vulnerable groups like Dalits and Sukumbasi (see definitions listed at the end of the article) face constant fear of eviction. This uneven allocation, poor access and unsecured tenure of vulnerable groups over the land they hold triggered various political unrest [4], civil movement [5,6] and even an armed conflict [7-9].

With time elapsed and several restructuring of the political system, the land administration system has undergone various changes. Different commitments were made by key political parties and the governments in office to address these issues leading to some leapfrog policy improvements in 1964, 1989 and 2007 [10]. Three high-level land commissions and at least 12 landless problem resolving commissions were constituted to provide secured land rights to the landless. However, the problems remain [11]. The latest estimate shows that about $25 \%$ of the arable land with an estimated 10 million spatial units on the ground are off-register and the related land rights are legally unrecognized [1-3]. Around 1.34 million households consisting of around 25\% landless peasants and squatters called Sukumbasi, around 17\% landless Dalits and 57\% informal land-holders are living under informality and are under constant fear of eviction [12]. More than one-fourth of the households, mainly ethnic minorities, indigenous people and Dalits do not have their land to farm on [13]. These families cultivate land owned by the landlords under different tenure arrangements for a living which are mostly exploitative in nature. One such examples is share-cropping system wherein the peasant pays half of the farm production to the legally registered land owner [14-16].

The demand for access to land to the landless and tenure security for all was one of the triggers of the armed conflict (1996-2006) as reflected in the 40-points demand of the United People's Front [17]. After the Comprehensive Peace Agreement (CPA 2006) [18], a national consensus and a strong political will have evolved to resolve the historical injustice and the outstanding issues on land governance arrangements. The new constitution promulgated in 2015 [19] and the Local Government Operation Act 2017 [20] have guaranteed various rights to the municipalities including issues such as levying local taxes, providing local services and land development activities, management of local records and land management activities. The act has ensured the autonomy of local governments to devise their own rules and regulations related to governance, protection and utilization of local resources under their jurisdiction including the governance of rights on the land. They are also empowered to prepare long-term development plans, formulate policies and implement them. Land is a prerequisite for any kind of infrastructure development. Land tenure security is a must for not only increasing household income, food security and equity [21] but is also important for generating revenues by local governments that are crucial for financing their local development projects. However, the local government bodies lack sufficient technical know-how for land administration and management and related skills such as land surveying and mapping. Additionally, given the volume of work, surveying and mapping with conventional techniques would require thousands of highly skilled human resources, enormous budget and decades to complete the work [22]. On contrary, a fit-for-purpose land administration (FFPLA) system can record the existing situation of informal land tenure relatively quickly, within affordable costs and using a participatory approach without requiring highly skilled professional personnel and a costly infrastructure $[3,23]$. The FFPLA approach is well considered as an overarching tool in the Framework for Effective Land Administration (FELA) [24]. However, the actual implementation is contextual which differs from country to country. In this regard, the experiences and lessons learned from an earlier application of FFPLA for rehabilitation of displaced people in the post-earthquake context [25-28] catalyzed to test the approach in the context of providing land tenure security for the landless Dalits, Sukumbasi and informal settlers. 
Based on the experience and lessons learned from the two pilot studies in urban and rural settings in Nepal, a FFPLA implementation approach is discussed that is estimated to provide secure land rights at the national level, through the local level initiatives. A roadmap for nationwide scale-up is provided. The objectives of this study are:

1. To assess the suitability of the Fit-For-Purpose Land Administration (FFPLA) approach for identification, verification and recordation (IVR) of informal land rights in the Nepalese context; and

2. To validate the acceptability of locally initiated mapping results at the national level.

The remainder of the article is organized as follows: Section 2 describes the historical social discrimination, inequality in access to land and recent government initiatives to fill the gap. Section 3 presents the rationale for conducting this research, Section 4 highlights the methodology adapted while Section 5 elaborates the major results. Section 6 discusses the results, compare them in international scenarios and analyses estimated timeframe for nationwide scale-up as well as the potential policy implications and challenges. Finally, the conclusion of this research and future outlook are presented in Section 7.

\section{Addressing Social Discrimination and Inequality in Access to Land}

Nepal is an ethnically diverse country $[29,30]$ where discrimination on the basis of caste, ethnicity and gender has been prevalent for centuries [31]. The people of higher caste enjoyed social and political power while those from lower caste were discriminated. For example, the Civil Code of 1854 provided harsher punishments for lower caste people for similar offences compared to people of higher caste [32]. Moreover, it also institutionalized gender discrimination, especially providing inheritance rights on properties to only male members of the family. Ownership of land as a source of power was generally held by higher caste elites; peasants and low caste, especially Dalits, turned into indenture laborer and artisans. With the advance of democracy in 1951, Nepal started into the path of progressive provisions and to reduce the discrimination on access to land [10]. The constitution enacted in 1990 [33], the Interim Constitution 2007 [34] and the present Constitution of Nepal [35] have gradually become more inclusive and thus discriminations on the basis of caste and gender have been gradually diminishing. The Constitution of Nepal enacted in 2015 [35] prohibits discrimination on the basis of religion, race, gender, caste, tribe, origin, language or ideological conviction and proactive provisions on protecting rights of women and socially excluded groups do exist.

Land is the most significant asset in the Nepalese rural-agrarian economy. Nearly $60 \%$ of Nepalese population depend on agriculture for their livelihood [36]. However, land is concentrated in the hands of the few. The richest $7 \%$ of households own about $31 \%$ of agricultural land [37]. Size of holdings are marginal. In 2001/02 some $47 \%$ of the Nepalese farmers owned less than 0.5 hectare of land while in 2011/12 this was enlarged to $54 \%$ [38]. Additionally, 29\% of the rural households are landless [37] and up to 85\% of the rural households are described as "land poor" [31]. Five to seven million urban poor are landless squatters and have even lost their daily livelihoods in 2020 due to the COVID-19 pandemic [37]. Skewed patterns of land ownership have also been compounded by a deeply discriminatory and strictly hierarchical society that has excluded women, ethnic minorities and especially people of 'low caste' (particularly Dalits). Dalits comprising over $20 \%$ of the country's population possess only $1 \%$ of arable land [31], $75 \%$ of them are functionally landless [39]. Gender inequality in access to land is also prevalent in Nepal, though the female ownership is gradually increasing. To increase women's access to land, the Government of Nepal, through the Eleventh Periodic Three Year Plan (2007-2010), introduced tax exemption for registering land in women's name and under joint ownership of husband and wife [40]. Female ownership of land reached to 19.71\% [40] in 2011 with an increase of nearly 10\% from 2001 [41]. Land access has also significant impacts on the lives of indigenous people. Establishment of wildlife reserves and national parks in the territories of the indigenous people (especially of Tharu tribe) have displaced them from the land upon which they had relied on for generations. Many of them have turned into 
squatters after losing the ancestral land and traditional livelihood. Approximately $80 \%$ of Nepal's indigenous population are marginal landowners, meaning they have less than 0.4 hectare of landholding [14]. Recently, the Government has taken major steps to ensure land rights for all. It has adopted the National Land Policy 2019 [42] and has developed a FFPLA National Strategy for implementing secure land rights for all [2]. These two documents are the landmark provisions for addressing unresolved issues of security of tenure and inequitable access to land for landless, smallholders and informal settlers in the country. The FFPLA approach is considered to minimize the time involved in recording and registering the land rights at scale using locally trained "grassroots surveyors". The FFPLA National Strategy was mainly aimed at being implemented as a national-level program to deliver security of tenure for all by recognizing and legalizing all legitimate land rights across the country. It recommended to conduct two pilot studies, one in a rural and another in a peri-urban informal setting, in order to test the suitability of data acquisition and processing using the FFPLA approach [2]. This article provides the design and results of the two pilot studies and discusses the implications and recommendations for implementation at a national scale.

\section{Rationale of the Research}

The FFPLA approach is widely tested and discussed in the literature $[23,25,27,43]$. However, it is not extensively implemented on the ground at scale [22] except for a few African and Asian countries $[44,45]$ where the majority of land are not covered by the formal land administration system [45]. While the Nepalese formal cadastre covers about $75 \%$ of the arable lands and settlements, the rest are informally occupied. Providing secured legal tenure to these informal occupants through the conventional surveying approach and land administration is estimated to require a large number of professionally skilled personnel, a long timeframe and a huge budget [46], while it may alternatively be achieved quickly and affordably with the FFPLA approach. Nonetheless, the approach has not been widely tested in a country with the diverse culture, ethnic setup, varying topography and more importantly, having a hierarchical institutional setup as well as complex legal arrangements. Tenure security improvement is context dependent where an action-oriented research would be necessary to validate an alternative approach [47]. This article attempts to assess the application of the FFPLA country implementation strategy in Nepal [2] for IVR of informal lands through the local level initiatives and to confirm the suitability of the results obtained through the local level initiatives at the national level. The knowledge and experience gained from this research may encourage land academics, land professionals, land agencies, politicians and government decision makers to apply the approach in similar scenario. Furthermore, the methodology and procedure recommended in this article may be instrumental especially in low-income countries where managing resources for land administration with large amount of informally occupied lands and unsecured tenureships are an issue.

\section{Materials and Methods}

\subsection{Study Area}

The two pilot study sites were chosen representing two different characteristics: a dense urban and an open rural setting. While Ratnanagar Municipality has compact residential areas, Belaka Municipality Ward No. 3 is dominated by relatively open and large agriculture fields. In addition, Sukumbasi are dominant in Ratnanagar while informal land occupancies exist in Belaka. The diverse sites were chosen such that the success of the approach can provide lessons for nationwide replication. The locations of study sites are depicted in Figure 1. 


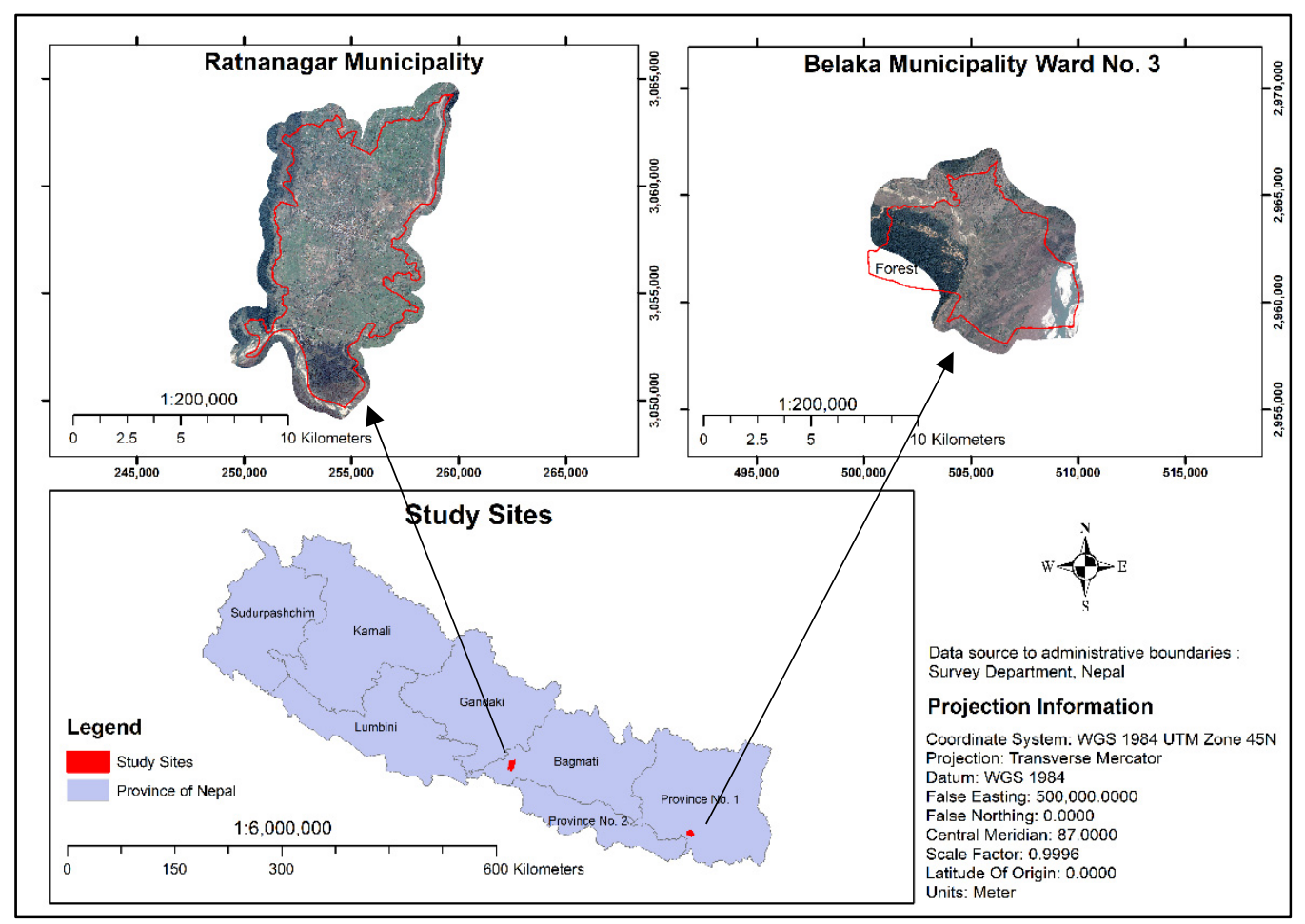

Figure 1. Study sites.

Ratnanagar Municipality lies in Chitwan District of Bagmati Province. Official Census is carried out every 10 years in Nepal. The next census is scheduled in 2021. In 2011, a population of 69,848 inhabitants was recorded which is spread over 16 wards (smallest administrative unit) of the municipality comprising a total of $68.68 \mathrm{sq} . \mathrm{km}$. area. No other consistent reliable data for both the municipalities are available. Though traditionally tribal Tharu communities were the majority of residents in the municipality, people of various ethnic groups from different parts of the country have migrated to the area due to its suitable topographic conditions, better livelihood opportunities and ease of accessibility through the East-West highway which has contributed to mushrooming of informal settlements. There are a total of 58 large and small informal settlements which host more than 1500 households of Sukumbasi and some seven thousand people scattered in an area of $0.41 \mathrm{sq} . \mathrm{km}$. Most of the households are residing at the government or public lands, some at the private lands legally owned by others and few at the lands owned by schools and religious entities like temples. A major proportion of the people have resided at the government or public lands for generations without having any land tenure documents. Only a few families have been identified as landless or informal settlers by different land-related commissions formed earlier by the Government of Nepal. They have been issued with documents recognizing them as such, however, the land itself is not formally registered. Some people have settled there during different political transitions since 1950s with the consent of local leaders associated with different political parties. Nevertheless, they have received no legal tenureship documents. Few families from indigenous communities like Mushahar, Tharu and others have been living on community land with common land tenureship, after being evacuated by natural disasters. This study covered all 58 informal settlements in the municipality.

Belaka Municipality lies in Udayapur District of Province No. 1. It encompasses $344.73 \mathrm{sq}$. $\mathrm{km}$. area which is divided into 9 wards with a total population of 42,386 as per the 2011 Census, out of which the selected pilot study area lies in Ward No 3. The total area covered in the pilot study is $10.33 \mathrm{sq}$. $\mathrm{km}$. Recently declared as an urban municipality, it is slowly emerging and still holds by and large rural character with most of the people engaged in agriculture. It is situated in the foothills of the Churia mountains 
and is mostly inhabited by migrants from the mountain districts in the north who have settled in search of fertile farming land in the past few decades. Few small settlements are inhabited by the traditional Tharu tribe but the rest of the area is inhabited by other different migrant ethnicities. As such, most of the land are still not registered and are under informal occupancy.

\subsection{Methods}

The FFPLA National Strategy (refer for Figure 12 of the National Strategy) [2] provided the basis for IVR of informal land rights through local level initiatives, which can later be recorded in the national register and reviewed for land right reforms. The authors of this article designed the methodology, supervised and closely monitored the process and initiated policy dialogues at the municipal, provincial and the national levels. The results from the two pilot studies jointly conducted by the Federal Ministry of Land Management, Cooperatives and Poverty Alleviation (MOLMCPA), UN-Habitat Nepal and the respective municipality, validated the proposed methodological approach and the FFP process as included in the strategy. IVR of informal lands is conducted through local pro-poor initiatives. The approach identifies and records the actual legitimate land rights through a participatory approach. More information on the FFPLA process for recognizing, recording and reviewing land rights by local-level initiatives in Nepal are well documented in [2]. This research considers all three frameworks of the FFPLA National strategy: The Spatial, Legal and Institutional Framework. It assesses a technological option of developing the spatial framework and informs on the development of legal and institutional frameworks to regularize informality for secured land tenure. The methodological workflow is presented in Figure 2.

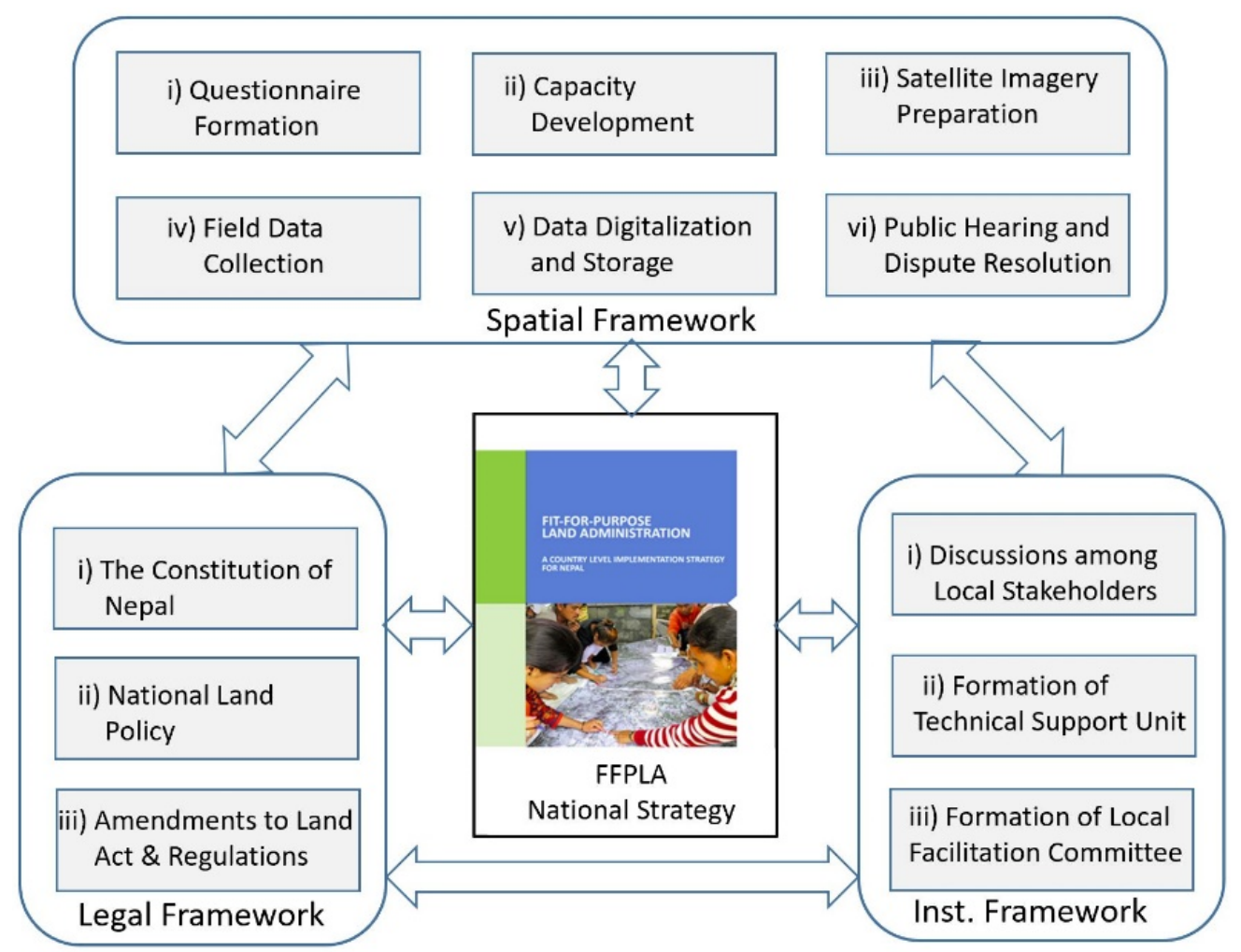

Figure 2. Overall methodological workflow of the research.

\subsubsection{Spatial Framework}

Spatial data acquisition on informality was divided into six main components as listed below:

(i) Questionnaire Formation 
After discussion with local stakeholders, a questionnaire was prepared for the purpose of identifying land occupancy, recording people-to-land relationship, time span and circumstances regarding their holding on the land, land use and information on the socioeconomic status of the family under informality. The questionnaire was required to identify the Sukumbasi as well as the status of the informal settlers. A consultation was held on the draft questionnaire with the Ministry and UN-Habitat Nepal. It was finalized after discussion with the stakeholders such as Community-Based Organizations (CBOs), civil society members and locally elected representatives of the municipality and finally, approved by the concerned municipality. The original questionnaire is in Nepali language and key points incorporated are provided in English in a simplified form the Appendix A, Table A2.

The final questionnaire contained questions related to family and family members details, occupation, income, land tenure documents, associated land rights, duration of occupancy, occupancy of land elsewhere in the country and present/potential risk on the land they utilize. The questions related to the socio-economic status were included to identify the Sukumbasi and the informal settlers' status.

(ii) Capacity Development

The training was conducted on Social Domain Tenure Model (STDM) tools and survey procedures for local enumerators identified by the municipalities, community leaders, $\mathrm{CBOs}$ and municipal/ward representatives. The training covered the introduction to the FFPLA but mainly focused on technical aspects-using imageries for identification of visual boundaries and their delineation, collecting locational data using Global Navigation Satellite System (GNSS)-enabled smartphone, documents digitalization and operations of STDM tools.

\section{(iii) Satellite Imagery Preparation}

Four-band natural color pan-sharpened ortho-rectified Pleiades [48] high-resolution satellite imageries of $0.5 \mathrm{~m}$ spatial resolution from the official vendor were used. Alternatively, satellite imageries from Google Earth may also be considered if their available resolution in the area fits the purpose. The imageries were mosaiced together in tiff format. True color composite orthophoto maps were printed at a scale of 1:1250. The scale is comparable with that of local cadastral maps. These printed satellite imageries were used by the enumerators, community members and the land-holders for identification, recognition and delineation of visible boundaries on the imagery through the participatory process.

Satellite imageries of 9th January 2018 were used for mapping informal settlements in Ratnanagar Municipality while those of 24th November 2017 were utilized for mapping agricultural fields having informal land tenure in Belaka Municipality Ward No. 3.

\section{(iv) Field Data Collection}

The municipal Ward Office informed/notified the landholders in advance regarding the date, time and venue for data enumeration and land survey. A survey team comprising of two enumerators trained as 'grassroots surveyor', a representative of the informal tenure holder community and the elected municipality ward leader visited the area with the questionnaire/form and the printed imagery of the area. The respective land/house-holder and the neighbors joined the survey team. First, of all, the team collected the information of the individual families, their land holdings, socio-economic parameters as included in the questionnaire and checked that it was all filled in appropriately. Photo images of the household head along with his/her spouse were acquired with a smartphone. The supporting documents were also photographed. The image IDs were recorded on the form so that they can be appropriately linked with the other data in the STDM software. The form was read aloud by a member of the survey team. When the participants agreed on the information, the head of the household/informant was asked to sign the form along with his/her thumbprints. This was attested by the community representative and the municipality/ward leader.

After a questionnaire survey for a group of households was completed, the participants/informants and the locals were asked to identify the houses and the land boundaries. 
The identified visible boundaries were delineated on the printed satellite imagery, given a unique ID and recorded on the questionnaire form. The form was verified by the representative of the ward office and the community representative. Finally, it was approved by the ward chairperson and stamped to get officially recognized by the municipality.

Due to the very small size of spatial units and congested settlements in Ratnanagar Municipality, visible boundaries were non-existent or could not be recognized on the satellite imageries and, instead, Global Positioning System (GPS) coordinates of individual houses were collected through a smartphone. Further, the surveyors visited the doorsteps and informants were asked to identify their house in relation to the roads and neighboring houses which was marked on the printed satellite imagery. It was done this way in order to cope with the inaccuracy of the point coordinates obtained through the smartphone's GNSS.

Data collection and boundaries survey work for Ratnanagar and Belaka were respectively conducted between March-September 2019 and January-July 2019.

\section{(v) Data Digitization and Storage}

STDM tool was customized to incorporate data as per the respective questionnaires. Local data entry personnel, trained on data entry and digitization using STDM, undertook data entry from the questionnaire and referred to the satellite imagery with delineated boundaries for digitization on QGIS. The data collected through the questionnaire survey was digitized and imported into the STDM (see Appendix A Figures A1 and A2). The images of the household head together with the spouse when applicable, as well as images of the house, citizenship certificate and other supporting documents, if available were linked with the respective data. The pdf copies of the filled-in questionnaire forms were also inputted as evidence of field enumerated attested/certified information.

(vi) Public Hearing and Dispute Resolution

A public hearing was held at each of the communities to validate the information collected through the household's survey and participatory mapping of informally occupied lands. In addition, residents' active participation, data entry staffs, field enumerators, municipal/ward representatives and community leaders contributed to the validation process. The disputes, if any, were sorted out by a local judicial committee. Necessary changes recommended by the committee were updated on the database.

Finally, the mapping cost was estimated considering the direct cost for satellite imageries procurement, human resources costs for field data collection and verification. However, the mapping costs do not include pro bono costs incurred by the implementing partners in terms of computer hardware, customization of STDM software, providing training and technical guidance and monitoring.

\subsubsection{Legal Framework}

The FFPLA country-level implementation strategy [2] is the key concept which is kept in the center of this research. The legal framework in this strategy envisages flexible and implementable provisions in existing policy and legal frameworks and recommends such amendment to existing Lands Act and Lands Regulation, which can be applied further for addressing informal tenure on land. In this context, some other soft policies such as Voluntary Guidelines on the Governance of Tenure (VGGT) by FAO, which is also referred by the FFPLA strategy, were also taken into account. The VGGT explicitly suggests to identify, record and respect legitimate tenure rights on land [49]. Addressing the legal framework requirements was divided into three main components as listed below.

(i) The Constitution of Nepal

Fundamental concept and basic guidelines for this research is taken from the Constitution of Nepal [35], which made a provision for addressing the issue of land-lessness by providing land to the landless farmers and shelter/house to the homeless. The Constitution mandates for one time appropriation of land to the landless Dalits from the state and addressing the issue of informal settlers. 


\section{(ii) National Land Policy}

This research was designed to achieve the aspiration of National Land Policy 2019 [42], which advocates defining informal tenure, recognizing it and addressing the problem of informality by regularizing the rights of settlers on that land. The policy also assures the equitable access on land to the marginalized people.

\section{(iii) Land Act and Land Regulation Amendments}

The research activities were conducted vis-à-vis ongoing discussions on the legal framework and informed on appropriate legal amendments in terms of the 8th Amendment to the Land Act [50] and the 18th Amendment to the Land Regulations [51] which have now come into place. Policy dialogues among stakeholders held (see dates in Appendix A, Table A1) at the municipal, provincial and the national levels provided inputs for the necessary amendments. The legal amendments were proposed to accommodate the process of spatial data acquisition and institutional arrangement as the former land legislation did not allow regularizing and formalizing the informal land rights. This kind of landholding was then legally considered as an encroachment on the Government/public land and the people settled therein were, in principle, subject to eviction.

\subsubsection{Institutional Framework}

The institutional arrangement was tested by ensuring the involvement of local government authorities. The Ministry led the process on the policy and management front. The concerned municipality planned and operated the whole IVR process of the people-toland relationship at the local level and submitted the records, approved by the municipal council, to the Ministry. Addressing the institutional framework was divided into three main components as listed below.

(i) Discussions among Local Stakeholders

Discussions were held with stakeholders before the questionnaire formation, to seek their suggestion on the questionnaire as well as during the survey works. The municipalities leader and officials, CBOs, NGOs working in the field of land rights, civil society members and land occupants took part in the local level discussion and provided important feedback.

(ii) Formation of Technical Support Unit

A unit of locally trained surveyors/enumerators was constituted for data collection in the municipality, digitization and linking into the QGIS plug-in STDM. The co-authors of this article and the local UN-Habitat staff guided the work and were occasionally present on the site to sort out any technical issues during the data collection, form digitization and to provide support of using the STDM.

(iii) Formation of Local Facilitation Committee

Ward level local facilitation committee was formed to support the technical support unit to collect and verify the data in the village blocks. This local committee was aimed to inform, aware, mobilize and motivate local people to cooperate with the survey team. The committee was also involved in the adjudication process of land rights. The validation process was inbuilt at different steps. In case of any dispute regarding rights and occupancy on the land among the neighbors, the committee was responsible to facilitate the dispute resolution process in the local judicial committee led by the Deputy Mayor of the municipality. A supervisory team consisting of municipal representatives and local staffs of supporting Non-Governmental Organization (NGO) was present in order to guide, coordinate and help manage the data collection. The Municipal Council, after the resolution of disputes, if any, finally approved the data and inventory of the people-to-land relationship collected by the team in the field. 


\section{Results}

The two study areas selected for this research-whole of the area under informality in Ratnanagar Municipality of Bagmati Province and Ward No. 3 of Belaka Municipality of Province No. 1-are diverse in characteristics. Agriculture land use is dominant in the Belaka Municipality where physical boundaries are visible and identifiable on the printed satellite imagery. In Ratnanagar Municipality, dense residential areas with tiny spatial units hardly identifiable on the available satellite imageries are prominent.

\subsection{Spatial Framework}

\subsubsection{A Pilot Study in Dense Urban Setting (Ratnanagar Municipality)}

A total of 1504 households consisting of 1517 spatial units from 58 communities distributed across 16 wards of the Ratnanagar Municipality were mapped by 6 groups of enumerators in 7 months. The STDM database was configured to store all the information collected from the field. The information obtained through the questionnaire survey was digitalized and first stored in spreadsheets. The questionnaires provisioned to collect documents such as certificate of citizenship, proof of the people living at that place such as voters' list or voters' card, local government's recommendations, certificates from community clubs or institutions and/or facilities provided by the municipality such as certificates of electricity connection, telephone connection, drinking water supplies or any other developments on the particular land. Photo images of these documents were captured by locally deployed grassroots surveyors using a smartphone which was later linked with the people-to-land relationship maintained in the STDM software. Where there are no such existing documents, a validation through participatory enumeration and certification by the ward representatives provided the evidence.

Spatial units were digitized on the QGIS as point features (Figure 3), with reference to GPS coordinates and the locations marked on the printed satellite imagery used for the land surveying. The same satellite imagery was used as a backdrop for the designation of the spatial units on the QGIS. Attribute information was imported into the STDM and linked with the respective spatial units. Relevant images of household head and the spouse, houses, filled-in and officially certified questionnaire forms and the supporting documents were uploaded and linked to the respective data. The inclusion and linking of these data and documents in the GIS platform enabled to query information based on parameters of the people-to-land relationship and perform location-specific analyses, for example. Likewise, linking documents and scanned questionnaire forms provide proof for legal validation.

The data collection to verification tasks were completed with an average of 7 parcels per day. The average costs for satellite imagery, field data collection, result verification and data entry were reported to be 7.40USD per parcel.

\subsubsection{A Pilot Study in Rural Setting (Belaka Municipality Ward No. 3)}

A total of 1783 households consisting of 3373 spatial units were surveyed in the Belaka Municipality Ward No. 3, also in seven months. Similar to the method applied in Ratnanagar Municipality, data were converted to digital form. Since the informal lands in the ward are dominated by agricultural land use, they were generally easy to delineate on the printed satellite imagery (Figure 4). Hence, the field boundaries were digitized (see Appendix A, Figure A2) using the imagery on the QGIS. All the data were imported to the STDM software and supporting documents including the pictures of the household head and the spouse were linked, as in the case of Ratnanagar Municipality. The inclusion of such data and documents in the QGIS enabled performing different types of spatial and non-spatial analyses, as has been described for the Ratnanagar case. Further, linking of supporting documents and the scanned questionnaire forms supported evidence for legal validation. 


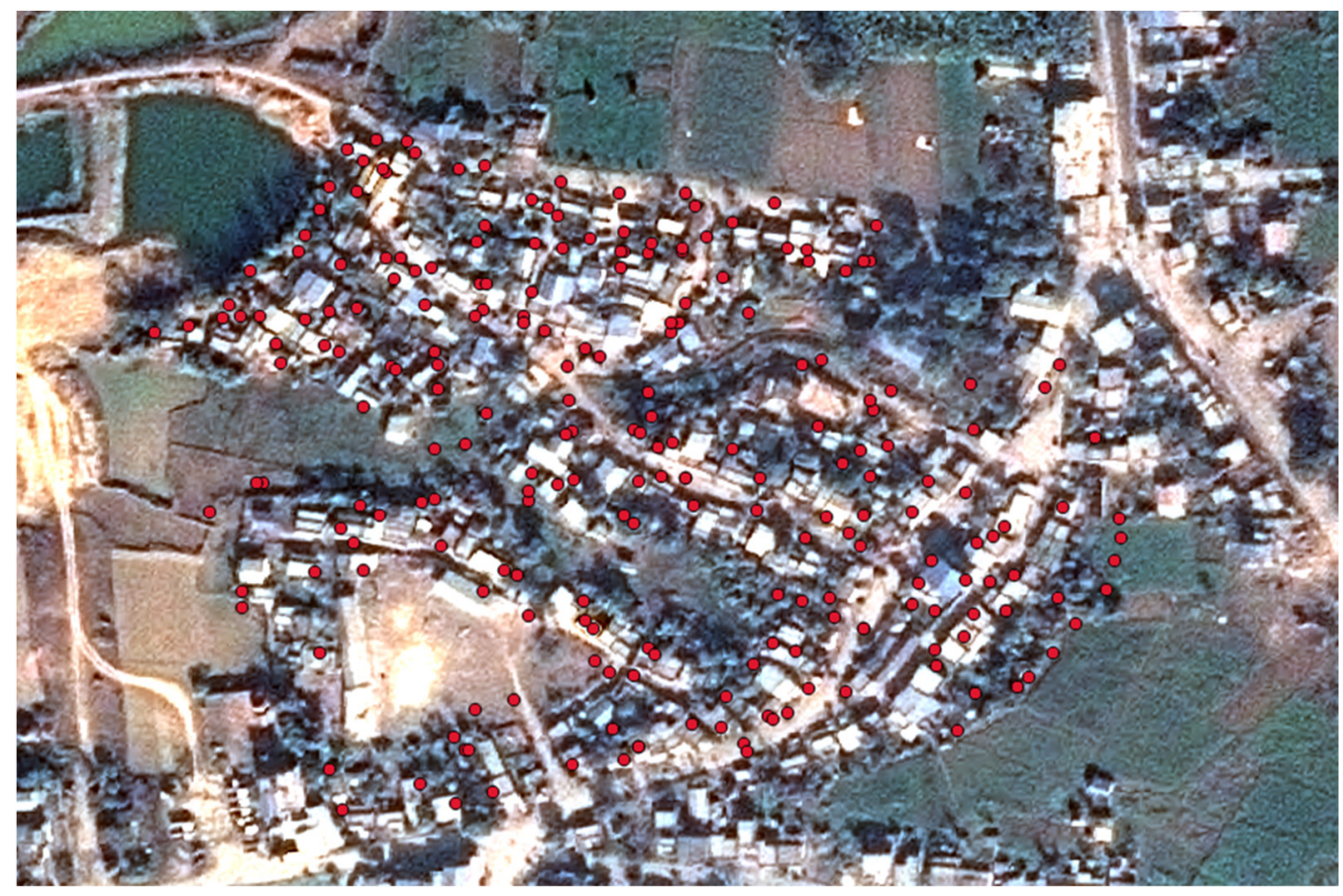

Figure 3. Identification of house/property in one of the compact settlements of Ratnanagar Municipality. The individual house location is shown with red-colored dots with satellite imagery in the background.

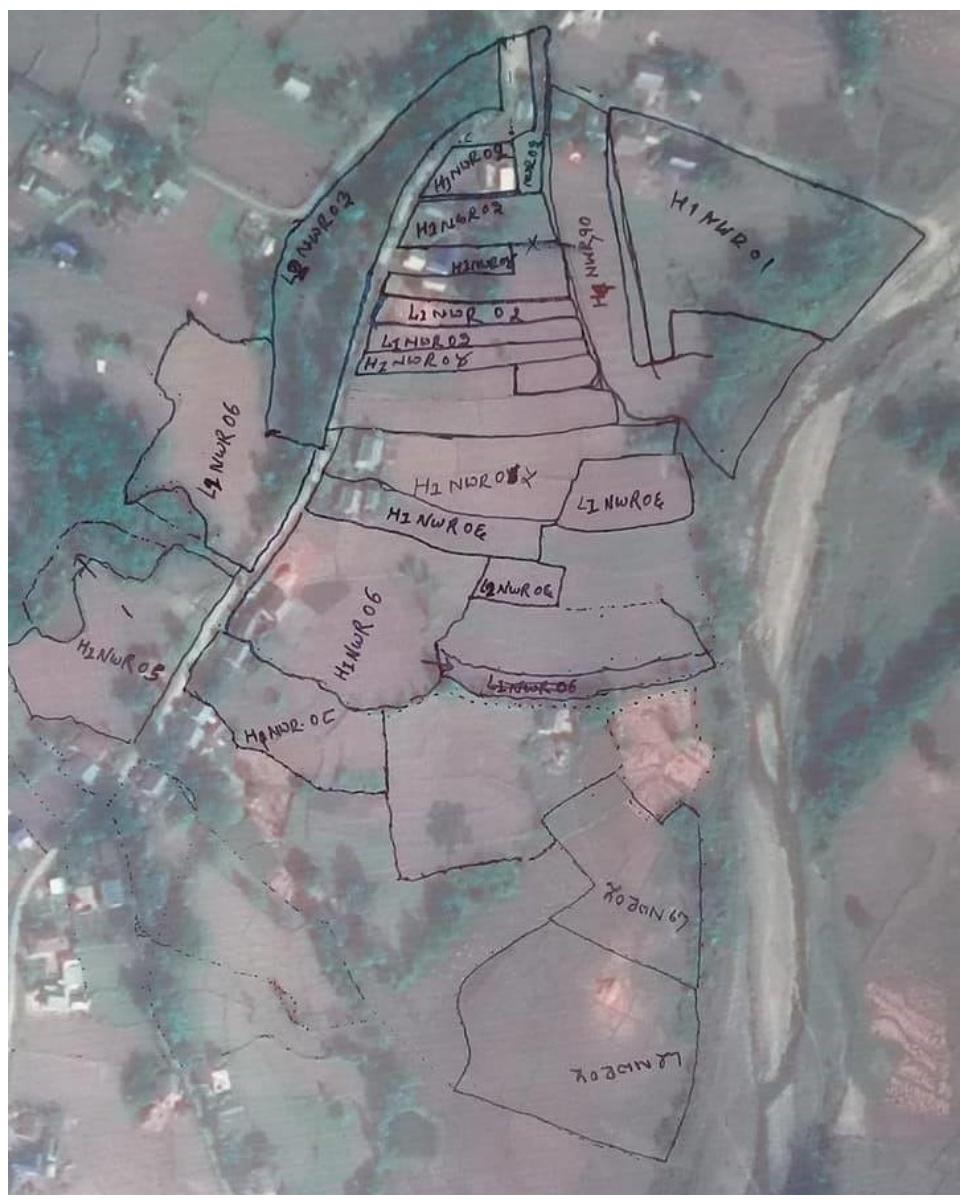

Figure 4. Delineating and coding spatial units on the printed satellite image map. 
The data collection to verification tasks were completed with an average of 16 parcels per day. Likewise, the direct costs for satellite image procurement, data collection, verification and data entry were 3.11USD per parcel.

\subsection{Legal Framework}

Various new legal provisions were made in the 8th amendment of Lands Act and the 18th amendment of Land Regulations by incorporating recommendations and feedback from the municipal, provincial and national-levels stakeholders discussions, which were conducted during the pilot studies. The informal occupancy on the land that was considered an encroachment, can now be awarded a tenure certificate after necessary IVR process. Similarly, the study did inform on the typology of land areas under informal tenure which reflected as ceiling on the land area to be granted to the landless, landless Dalits and informal settlers. A different ceiling amount for rural agricultural land and urban residential area, as recommended, is now incorporated in the new Land Regulations.

Provision of regularization fee was recommended by the stakeholders and municipal corporations during field study and discussions. The regularization fee should be based on various factor such as location of land, land use class, land value and infrastructure and associated services in the surrounding. Similarly, it was recommended that a higher fee should be charged to the settlers with good socio-economic status whereas less fee should be charged to socially and economically disadvantaged and marginalized groups. The landless and landless Dalits should be provided land without charging any fee. The Land Act amendment incorporated these recommendations and such provisions are now incorporated in the land legislations.

A new institutional setup was also recommended by the study which is now materialized in the legislation. The Land Issues Resolving Commission (LIRC) is setup at the center. Along with this legislative provision for institutional setup, an executive order is now issued for its smooth operation and various procedure and guidelines have been developed for execution of the task at the local municipality level in accordance with the lessons learnt from the pilot studies.

\subsection{Institutional Framework}

The landholders received social and local government's recognition after mapping and local-level validation. The record was maintained by the municipality after the validation by the community and provided a document to the occupant mentioning that his/her application was recorded. However, they will eventually get a land ownership certificate once the Ministry approves the legitimacy of the land rights in line with the recently amended legal framework.

Discussion with the stakeholders helped formulate more relevant questions and improvise them. More importantly, collecting information as well as land survey was smooth because of inclusion and active participations of the occupants, CBOs, NGOs and municipalities officials. Provision of local facilitation committee helped verify information and correct any falsified claims of the occupants. Dedicated involvement of local government leaders and authorities was instrumental for planning and collection of the people-to-land relationships.

In Ratnanagar, there were issues related to land informally occupied in the private land or land owned by entities like School, Temple etc. The municipality board and other stakeholders had agreed before the start of the participatory mapping exercise to exclude them. Three family disputes surfaced during the enumeration. Though female siblings were occupying the lands and houses, they were claimed by their male siblings stating that the lands were temporarily allocated to the sisters. The local facilitation committee resolved these disputes and the lands were enumerated in the names of the female siblings. All disputes as evolved did resolved at the facilitation committee and no dispute was reported to the municipal judicial committee in Ratnanagar. In Belaka, three dispute cases were resolved through the local facilitation committee and enumerated as such. In another 
dispute, a spatial unit was claimed by a maternal family of the present holder stating that it was handed over for temporary use only. After not being resolved by the local facilitation committee, the dispute was referred to the judicial committee which decided to enumerate the land in the name of present holder. During enumeration stages, there used to occur debates or discussions regarding the land boundaries and their identification/delineation on the imagery. However, they were all resolved with participatory approach. This is a strength of the approach where chances of resolving disputes by the stakeholders themselves are high.

\section{Discussion and Recommendations}

The results obtained and the lessons learned from these two pilot studies were instrumental and have contributed to developing the spatial, legal and institutional setups for IVR of landless Dalits, Sukumbasi and informal settlers. The methodological development provided a mechanism to IVR of the people-to-land relationship. The two pilot studies provided information on the socio-economic conditions of the Sukumbasi and informal settlers and the type of holdings under informal tenure. Several cases were reported that need to be vacated due to cultural conflicts, environmental hazard risk and restrictions on land use. These cases were brought to the attention of the government legislation drafting team for necessary amendment in the legislation for incorporating issues related to the relocation.

Data collection, verification, storage in the STDM software and approval from the municipal office were completed in 7 months in both pilot areas with an average mapping cost of 3USD and 7.5USD respectively in rural and urban settings. The costs are contextspecific which may differ between locations. Furthermore, time and cost may be reduced when the work is conducted at scale. The higher mapping cost in the Ratnanagar may be partly attributed to scattered settlements, comparatively expensive human resources due to the area being more urbanized and complexity in identifying compact houses on the satellite imagery.

The FFPLA tools have been applied in other countries too [44,45]. Rwanda has completed land registration of more than 11.4 million parcels with four years and at an average cost of around 6USD per parcel $[44,45]$. Similarly, Ethiopia and Tanzania have reported average costs of less than 10USD per parcel $[44,45]$ when the mapping were completed at scale. Further, these studies suggest that the data collected and the system administered at the local level could be migrated to national systems provided there is due consideration for the underlying data model and mapping standards.

The experiences from India having social and caste-based structure similar to Nepal confirm that the implementation of FFPLA can be achieved at scale through local level initiative [52]. Similar to Nepal, India has 31\% landless households, majority of whom belong to Dalits, tribal and lower caste communities [53]. As is evident like in India and other countries, these most vulnerable sector of the population will benefit from implementation of the FFPLA approach.

The experience of mapping informality in the pilot study sites infers that the FFPLA approach could be used to provide secure land tenure for all through local level initiatives, both faster and cheaper and support results as expressed in the political will. Further discussions have been divided into three themes corresponding to each of the FFPLA frameworks: The Spatial, Legal and Institutional Framework. Likewise, potential policy implications and time estimations for nationwide mapping of informality are also presented.

\subsection{Spatial Framework}

Spatial units' size in Belaka Municipality were generally rather large and the physical boundaries were identifiable on the satellite imagery that was then sufficient to map the area. The grassroots surveyors and occupants were able to recognize and demarcate the field boundaries. From field visits of few areas in other wards of the municipality, it was observed that the field boundaries were sometimes obscured by vegetation. Land 
boundaries in dense settlements in the other areas of the municipality were also difficult to be identified on $0.5 \mathrm{~m}$ resolution satellite imagery.

In the case of Ratnanagar Municipality, the spatial resolution of available satellite imagery did not support the identification of actual land boundaries (polygon) due to the presence of compact houses. Thus, the use of the smartphone's GNSS was tested for collecting the location of each house. However, horizontal position obtained from the smartphones contained a random error of up to 10m [54] which overlaid on satellite imagery showed a shift of spatial unit's location. Some adjustment with reference to the location and physical boundaries on the ground itself was necessary. Thus, houses were marked as point features utilizing neighborhood information, e.g., roads and adjacent houses. A similar approach has been reported in other research as well [25].

Hence, in line with recommendations of the FFPLA approach [23] and preliminary unpublished results obtained using drone survey from the dense area of Belaka Municipality, the authors recommend applying a hybrid method of boundary mapping using drone imageries in densely populated areas. The use of ultra-high-resolution drone imageries have shown promising results for boundary mapping in compacted areas as reported elsewhere as well [55]. Furthermore, conventional ground survey methods should be applied where the number of spatial units is low and the size of the plot under consideration is very small. This is recommended to cut down the cost of drone surveys, discard extra work of securing flight permissions as well as to reduce the technical complexity of drone survey and data processing and arrange additional computing resources, for smaller areas. Such conventional surveying methods or drone imageries should be restricted to locations where delineation of land boundaries and area computation is mandatary and the price of land is very high and therefore-demanding more accurate mapping of the boundaries.

As an alternative, point cadastre $[1,56]$ may be used in the case of very dense settlements as tested in Ratnanagar Municipality when this is supported by the legislative framework. To improve the accuracy of point locations, handheld GPS can replace smartphone's GNSS which can provide an accuracy of approximately $3 \mathrm{~m}$ when the Wide Area Augmentation System (WAAS) signal is available [57], but this may as well be considered when the size of spatial units is adequately large. This would be a much cheaper and faster way of data collection $[1,56]$. If the WASS signal is problematic, mapping grade GNSS equipment in deferential mode can be used which can provide an accuracy of 1-3 $\mathrm{m}$ [57]. Nonetheless, if boundaries are not demarcated, conflicts may arise in the future where the price of land escalates and as such should be supported by the Alternative Dispute Resolution (ADR) mechanism within the legislative and institutional framework. As is evident, surveying is a tool to make a "good estimate" of the true value and all survey estimates are "good enough" when they serve the purpose. Accuracy assessment was not the purpose of this study; however, several studies have indicated that the FFPLA approach provides good enough results [58] while the accuracy of conventional techniques like plane-tabling applied in many areas in Nepal $[59,60]$ could be even more challenging.

\subsection{Legal Framework}

Despite the strong political will to resolve the issues of informal landholding and securing tenure for all after the proclamation of the new Constitution in 2015, the lack of an appropriate legal framework was considered as one of the barriers. The existing institutions managing the land administration, dealt only with the formal land tenure as per the (then) legal system. The policy discussions and testing of appropriate tools were conducted simultaneously. The National Land Policy [42] adopted in 2019 accepts and recognizes the existence of informal tenure and realizes the need for its formalization. Simultaneously, the FFPLA National Strategy [2] was developed to conduct the formalization process and an implementation framework was proposed. Piloting the strategy at two sites as pilot studies, representing a rural and a semi-urban with dense settlements, suggested the need for an appropriate legal mechanism to carry out the formalization process smoothly. Thus, the 8th Amendment to the Land Act 1964 [50] adopted in 2020 accommodates the substantial 
issues and the 18th Amendment of Land Regulations [51] adopted in 2020 complements to define procedures of the formalization process. The specific dates for major activities are tabulated in Appendix A, Table A1. Necessary executive orders, procedural guidelines and directives have been issued to speed up the process.

This framework provides a legal basis for identifying the various kinds of land rights of the settlers, recognizes and verifies these rights and records them properly in the system. The Act defines the settlers as either landless or informal settlers. As per the Act, the landless (landless Dalits and Sukumbasi included) will be able to get land and land title (ownership certificate with due restriction) over the specified land without paying a regularization fee whereas the informal settler having some registered land elsewhere should pay a specified regularization fee to get it formalized up to a specified area. The informal settlers must give-up the extra land exceeding the defined area threshold to be taken over by the Government. Along with the rights established on the land, the law also imposes some restrictions for the settlers on the land. The title will be issued with the restriction on the right to dispose of the property for 10 years except for inheritance by legal heirs. The restriction also ensures that the settler would not dispose of the land rendering him/herself landless again. The restriction on sale for 10 years is marked on the land record (Shresta-a copy of the ownership certificate that stays at the District Land Revenue Office) and the ownership certificate itself. It is believed that the family may become financially independent within this restricted period after which they can enjoy absolute rights over the land. The Act has a strong gender focus with a provision that the land must be registered jointly with the husband and wife when both the spouses are existing. The Act provisions evacuation of illegal occupancy and relocation of landless residing in unsecured areas and area designated for protection due to cultural reasons and land use restrictions.

The new legal framework also encompasses the technological (spatial) and institutional arrangements for carrying out the formalization process. As per the law, the Land Issues Resolving Commission (LIRC) and the municipality can adopt any technical tools and methodology appropriate to collect spatial information on the settlers and their land rights including spatial boundaries and preparation of cadastral maps. This is evidently based on the FFPLA National Strategy and supports the application of appropriate, hybrid and non-conventional technologies which is faster, cheaper and good enough to address the current needs and is upgradable and updatable to the needs of specific situations. Similarly, the legal framework makes a provision for the participation of local governments and other stakeholders in the formalization process. The need for these kinds of mechanisms in the new amendment of the law was realized as informed by the pilot studies whose outcomes are discussed in this article. Given the volume of work and the available resources-human, financial and time- the FFPLA approach is considered as the viable and scalable solution. Hence, the legal provisions as amended and now existing provide a path for mapping informality initiated by local governments, which would allow to provide legal land rights over the lands to the legitimate holders.

\subsection{Institutional Framework}

Whilst the pilot projects were conducted, the legislative and the institutional frameworks were under discussion and were not fully in place. As the legitimacy of the survey could not be fully assured, collecting authentic information from the household with the relevant supporting documents was a big challenge for the enumerators. The proper training provided helped them in getting reliable information. A similar approach is reported to be used elsewhere [61-63]. Further, the active participation of the local representatives and representatives from the organization of local informal settlements was instrumental. As they knew every detail of the respective households, it helped in verifying the information provided by the households to confirm that the information is true. In addition to inclusive and flexible community awareness programs, the role of committed representatives from the community and local offices supported obtaining more reliable and quality 
datasets. Such experience has also been observed in Indonesia, for example [22]. It is understood that the effective mobilization of these representatives and active participation of local elected representatives throughout the household survey was crucial for successful collection of authentic information with proper evidence.

Considering the importance of the participatory approach, the needs of local government initiatives and in line with the recent provisions of the legislative and institutional frameworks, a process workflow (Figure 5) has been devised. It is based on the experience and lesson learned from the pilot studies and after broader discussions with the stakeholders. It encompasses the identification of informal land tenure, their survey and mapping, verification and the distribution of land ownership certificates. The municipalities should play an active role in the identification and mapping of existing scenarios and planning land distribution/formalization/relocation/resettlement in line with the legislation and as foreseen as appropriate in a given municipal context. This will provide a technical framework for nationwide scale-up of the FFPLA approach from data collection on the people-to-land relationship and adjudication and distribution of land title to the landless and informal tenure-holders in Nepal. The district committees should support the municipalities in mapping and planning activities while the provincial government should facilitate inter municipalities relocations/resettlements activities, together with the identification of lands under hazard risks as mandated by the legislation. The LIRC [64], as constituted, is now mandated to give final approval of the legitimate land rights recorded at the local level and award ownership certificate to the eligible person/family. Additionally, the LIRC should design and develop a centralized system following specific data model, prepare uniform templates, guidelines mapping standards and standard operating procedures (SOPs), guide with specific methodology to the municipalities.

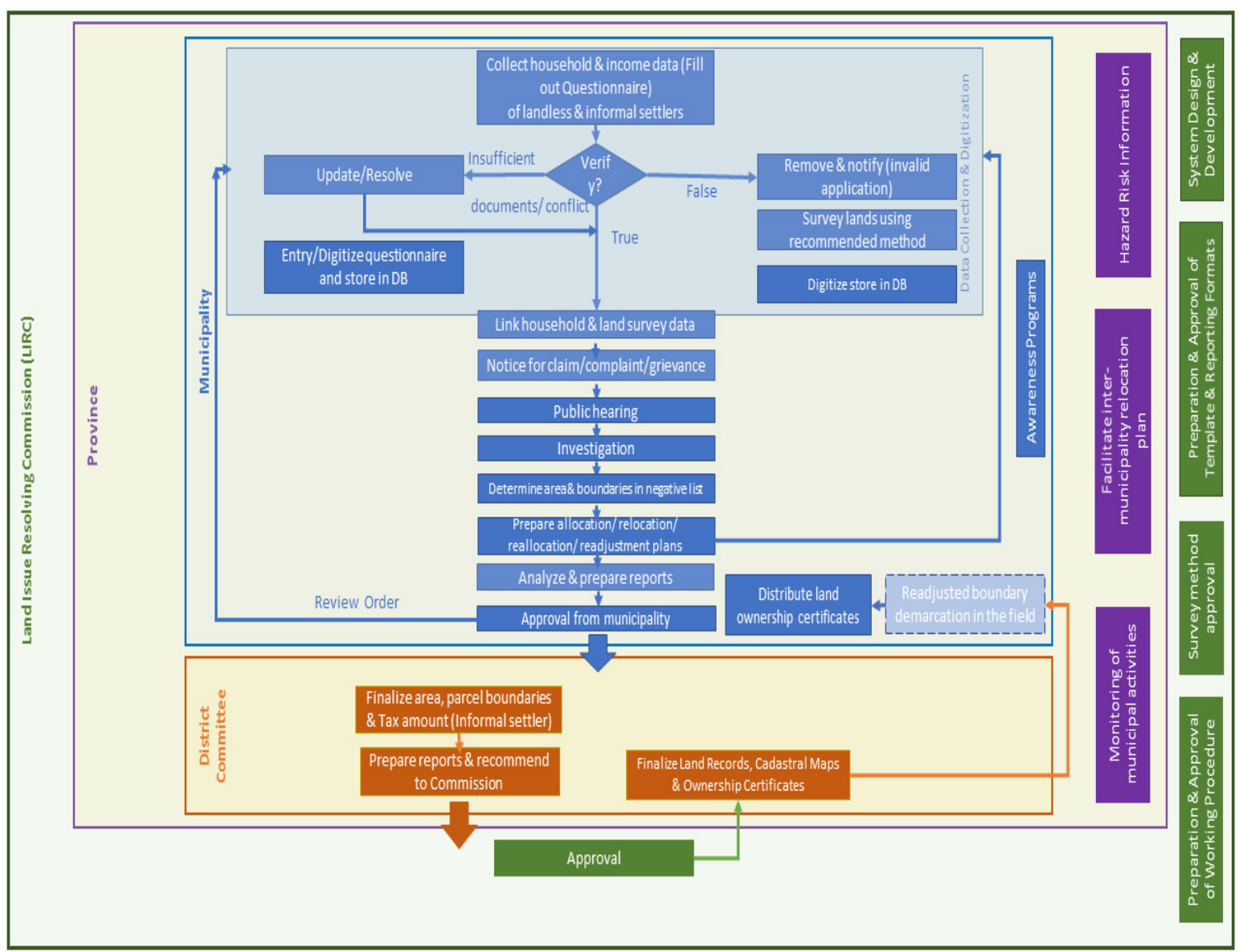

Figure 5. Process workflow depicting roles and responsibilities of different institutions (The box with dashed boundary is not mandatory). 
Data management and institutional arrangement relating to integration with the existing formal land administration system need due consideration. It is recommended that a central web-based system be developed which should host nationwide data of people under informality, spatial units and people-to-land relationships. Further, the system should host satellite/drone imageries, administrative boundaries and other relevant data that would be used for mapping informality. The system should be maintained and governed by the LIRC where appropriate access would be given to the municipalities, the district committees and the provincial governments. When the formalization of informal spatial units is complete by delineation of the land boundaries and distribution of land ownership certificate to the holders, all relevant records should be handed over to the relevant land administration entities. While spatial data should be transferred to the Survey Department, non-spatial information should go to the Department of Land Management and Archives (DOLMA) who will maintain the records at the center providing necessary use and update rights to the municipalities for day-to-day service delivery. Since a large number of land parcels would be added to the formal system after the formalization of informal tenureship, it is expected that the service demand will increase after the release of restrictions in 10 years. Hence, necessary human resources and infrastructure should gradually be developed, mainly at the municipalities for improved service delivery.

\subsection{Potential Policy Implications}

The implementation of the FFPLA National Strategy is expected as a huge policy shift considering the existing traditional and conventional surveying and mapping approach, complex legal and procedural phenomena and overlapping institutional silos. The pilot studies show that new and out-of-the-box technologies in surveying are suitable enough to acquire the data on the people-to-land relationship and the physical boundaries in comparatively less time and with limited financial and semi-skilled human resources. Similarly, newly enacted amendments in the land act and land regulations are expected to fill the past gaps and address the legal issues experienced in the past. This will pave the way to formalize and legalize the legitimate occupancy of informal settlers and provide land and title to the landless. Further, the newly developed institutional framework will ensure participation of beneficiaries and/or stakeholders which would facilitate hassle-free identification, verification and recordation of the landless and informal settlers for ensuring land rights quickly.

\subsection{Time Estimation for Nationwide Scale-Up}

With the 10 million spatial units reported under informality, IVR of these lands is estimated to be completed in 4 to 5 years if the implementation of the FFPLA approach is simultaneously replicated, respectively, at 150 to 100 municipalities with implementation at an average of 4 wards in parallel (refer to Table 1 for details). Nepal has 753 municipalities/rural municipalities, which are divided into 6743 smallest administrative units called wards (https: / / www.sthaniya.gov.np/gis/, accessed on 2 July 2021) A municipality/rural municipality has a minimum of 5 to a maximum of 33 wards, with an average of about 9 wards. The most time-consuming field work is conducted at the ward/municipality level and managed by the respective offices. While the district committees support the municipalities/wards planning and mapping tasks, the LIRC ensures mapping standards and consistency of the work. Thus, the FFPLA approach enables to work in parallel throughout the country. Furthermore, the semi-skilled grassroots surveyors can be trained at the local level. However, slightly uneven distribution of informality across ecological reasons and among municipalities may lead to slightly higher mapping time. Likewise, the management time for district level validation, revenue collection and final approval from the LIRC are not included in the time estimation which may further delay the final approval and providing land ownership certificates to the legitimate holders. 
Table 1. Time estimation for nationwide mapping of informal lands using the FFLA approach.

\begin{tabular}{ccc}
\hline Description & Estimates & Remarks \\
\hline $\begin{array}{c}\text { Spatial units under informality } \\
\text { Number of Spatial Units Mapped per } \\
\text { month (Urban Scenario) }\end{array}$ & $10,000,000$ & [12] \\
\hline $\begin{array}{c}\text { Number of Spatial Units Mapped per } \\
\text { month (Rural Scenario) }\end{array}$ & 482 & $\begin{array}{c}\text { as per the results of the two } \\
\text { pilot studies. }\end{array}$ \\
\hline $\begin{array}{c}\text { Average Number of Spatial Units that } \\
\text { can be mapped per month }\end{array}$ & 402 & $\begin{array}{c}\text { with an estimated } \\
\text { Urban-Rural spatial units } \\
\text { under informality of 30:70 }\end{array}$ \\
\hline $\begin{array}{c}\text { Estimated Mapping Time in Years } \\
\text { (Scenario 1) }\end{array}$ & 3.5 & $\begin{array}{c}\text { Simultaneous Implementation } \\
\text { at 150 municipalities with an } \\
\text { average of } 4 \text { wards in parallel }\end{array}$ \\
\hline $\begin{array}{c}\text { Estimated Mapping Time in Years } \\
\text { (Scenario 2) }\end{array}$ & 5.2 & $\begin{array}{c}\text { Simultaneous Implementation } \\
\text { at 100 municipalities with an } \\
\text { average of } 4 \text { wards in parallel }\end{array}$ \\
\hline
\end{tabular}

\subsection{Future Challenges}

Despite all these arrangements, the implementation is not without challenges. Hesitation of the traditionally trained surveyors and the beneficiaries who have seen instrument survey as a legitimate method in the past, in adopting new technologies such as satellite/drone imageries for boundaries demarcation may be one of the challenges. Similarly, conflicting interests of various stakeholders on the state land is another challenge, which might delay the process. Further, some of the newly formed local institutions in rural remote area may find difficulties in managing technological, human and financial resources to deal with the identification and mapping of landless, informal settlers and their land rights. In addition, coordination and supervision of work simultaneously in 100 to 150 municipalities at a time is a challenge. Additionally, concept of point cadastre is currently not supported by the existing legal provision which encourages increased application of drone imageries or ground-based conventional survey methods in dense settlements. Consequently, it may put more pressure on municipal resources and may cause delay in securing land rights for all.

\section{Conclusions}

Informally occupied lands were mapped using participatory methods and the FitFor-Purpose Land Administration (FFPLA) approach. Satellite images, GNSS-enabled smartphones and free and open-source software tools were used for mapping in two different scenarios-dense settlements and areas dominated by relatively large agricultural fields. The pilot studies conclude that the high-resolution satellite imageries and freely available open-source software like STDM could be used in a participatory approach by locally trained 'grassroots surveyors' to quickly and inexpensively map large areas which would otherwise require highly-skilled human resources, large infrastructure and decades of time for mapping while using the conventional approaches. Point cadastre can be used in dense settlements for quick mapping where accuracy is not an issue. Nonetheless, it should be supported by necessary legislation which is so far not in place in Nepal.

The two pilot studies recommend that the FFPLA approach, supplemented by hybrid surveying technologies with the use of satellite imageries, drone imageries and ground survey techniques when appropriate can be applied. The technologies, tools and methodology for a spatial framework would meet the demand of high political will for providing land to the landless Dalits and Sukumbasi and tenure security for all within a limited timeframe. The study did inform on the suitable options for the adoption of the legislative and institutional framework in Nepal. However, scaling the FFPLA approach nationwide and integrating with the existing land administration system is not without further challenges. 
The use of consistent data model, guidelines, uniform templates and mapping standards are recommended for nationwide scale-up.

Definition 1. Sukumbasi is a landless person/family without land country-wide and a financial status incapable of procuring a piece of land on their own.

Definition 2. Informal Settlers are persons or families utilizing some of land(s) without having a formal land tenureship, however, possesses land(s) somewhere in the country that is(are) legally registered in their (or their family) name.

Definition 3. Dalits were previously considered to be in the lowest caste and part of the socalled "untouchables". Nepal legally abolished the caste-system and criminalized caste-based discrimination, including "untouchability" in 1963.

Author Contributions: Conceptualization, U.S.P., R.R.C. and J.R.J.; methodology, R.R.C., J.R.J., J.D. and U.S.P.; software, U.S.P. and R.R.C.; validation, J.D., R.R.C. and J.R.J.; formal analysis, U.S.P., R.R.C. and J.R.J.; resources, R.R.C., J.D. and J.R.J.; data curation, U.S.P. and R.R.C.; writing—original draft preparation, U.S.P.; writing — review and editing, ALL; visualization, U.S.P.; project administration, R.R.C. and J.D.; funding acquisition, D.A., R.R.C., J.D. and J.R.J. All authors have read and agreed to the published version of the manuscript.

Funding: Funding of the publication costs for this article has kindly been provided by the School of Land Administration Studies, University of Twente, in combination with Kadaster International, The Netherlands.

Data Availability Statement: The data presented in this research are available on request from the authors except from the personal's data of the occupants.

Acknowledgments: The study is based on the findings of the UN-Habitat/GLTN funded project (Contract No. SAoC18-007 and SAoC-008) in Nepal. The authors would like to acknowledge the contribution of the Government of Nepal, Ratnanagar and Belaka municipalities, and National Land Rights Forum (NLRF) for partial co-funding. We would like to thank Lumanti and CSRC for their support in data collection.

Conflicts of Interest: The authors declare no conflict of interest. 


\section{Appendix A}

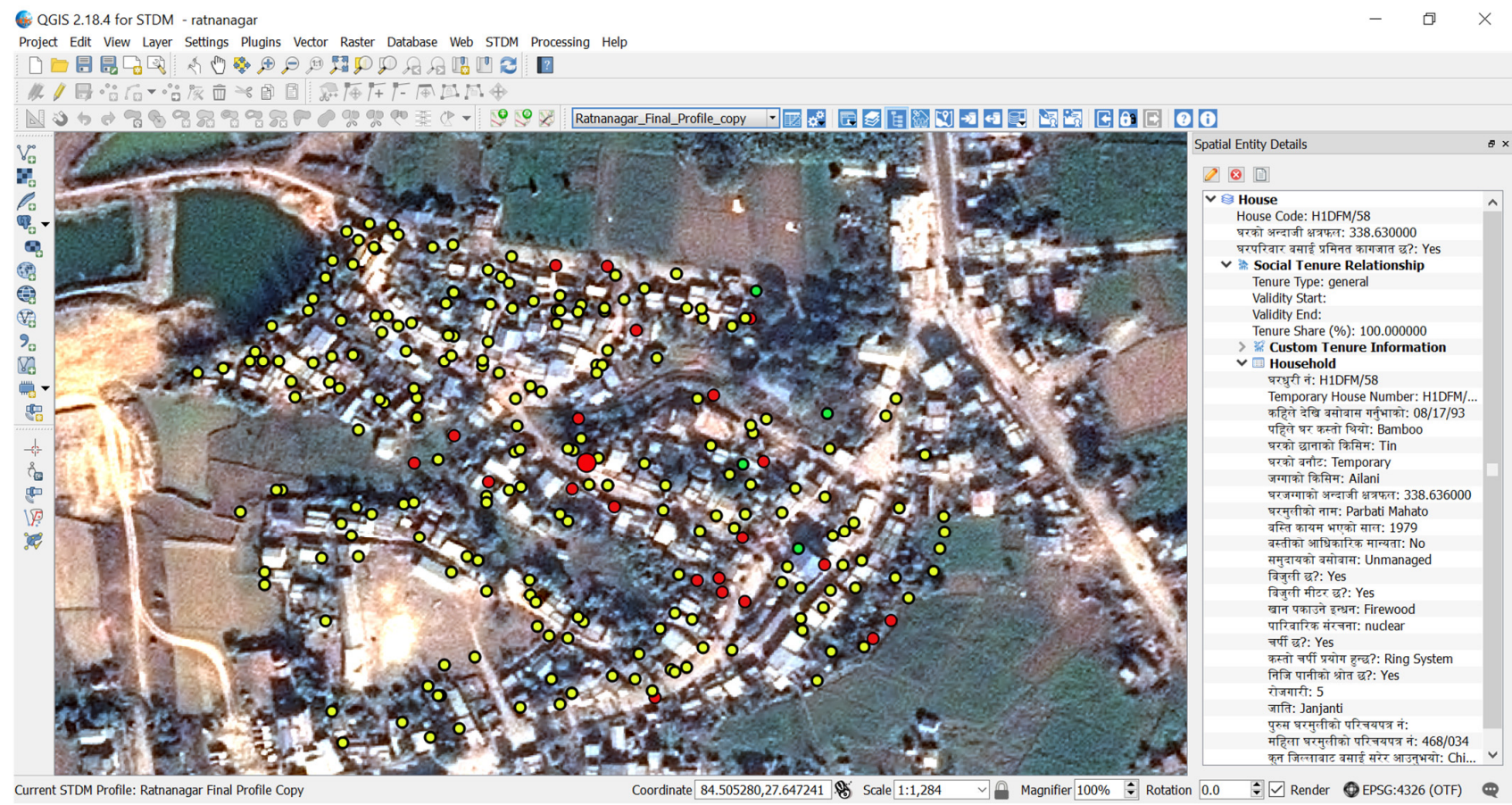

Figure A1. Identification of house/property in one of the compact settlements of Ratnanagar Municipality (shown with red colored dots with satellite imagery in the background; Red, Yellow and Green colored dots respectively represent temporary, semi-permanent and permanent houses) in compact settlements of Ratnanagar Municipality. The right most portion of the picture represents people-to-land relationship's parameters (in Nepali language) of a select spatial unit (depicted by the enlarged Red colored dot in the center).

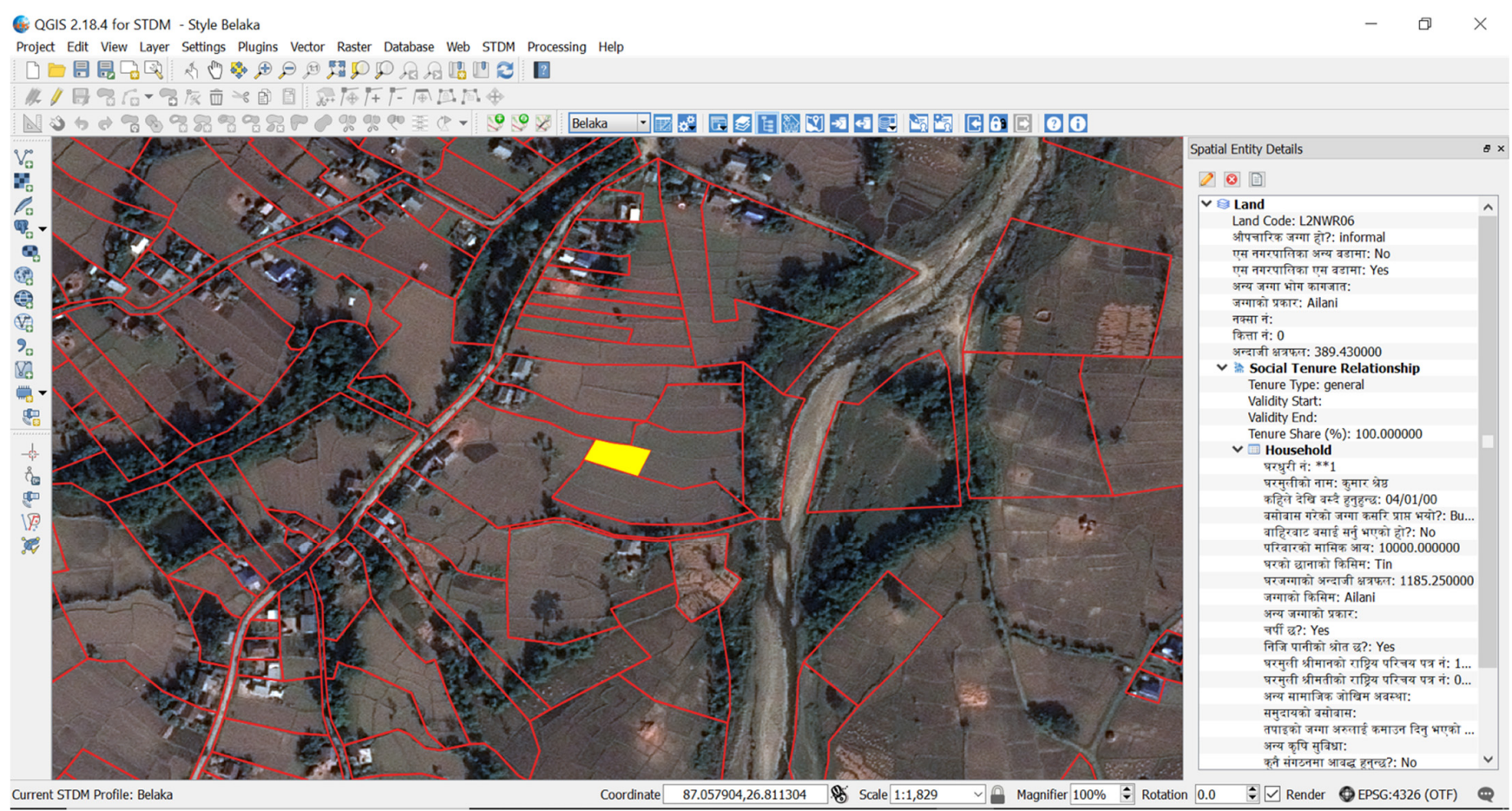

Figure A2. Delineated spatial units overlaid on satellite image in QGIS. The right most portion of the picture represents people-to-land relationship's parameters (in Nepali language) of a select spatial unit (shown in Yellow color). 
Table A1. Important Dates.

\begin{tabular}{cc}
\hline Framework Issues & Date \\
\hline Spatial Framework & 24 November 2017-9 January 2018 \\
Image Date (Belaka/Ratnanagar) & January-March 2019 \\
January-March 2019 & July-September 2019 \\
\hline Orientation on STDM tools and field-based training (Belaka/Ratnanagar) & \\
Survey Start (Belaka/Ratnanagar) & September 2018-May 2019 \\
Legal Framework & August 2019 \\
Consultation and Drafting Land Act Amendment & February 2020 \\
Land Act Bill passed by the Parliament & March-May 2019 \\
Land Act approved by the President & December 2020 \\
Consultation and Drafting Land Regulation Amendment & December 2020 \\
Land Regulation approved by the Cabinet & Institutional Framework \\
Land Regulation Act Published in Gazette & January 2019/January 2019 \\
\hline Frovincial dialogue on land issues and possible solution & April 2020
\end{tabular}

Table A2. Simplified Questionnaire (translated from Nepali language).

\section{Form and Basic Information}

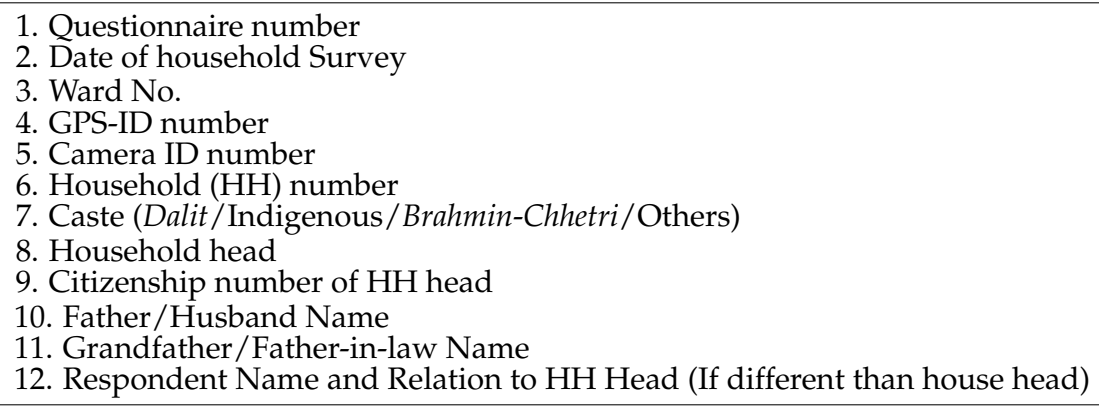

$\begin{array}{cc}\text { Section A } & \text { Section B } \\ \text { Family details for each adult member of the family } & \text { Land occupancy }\end{array}$

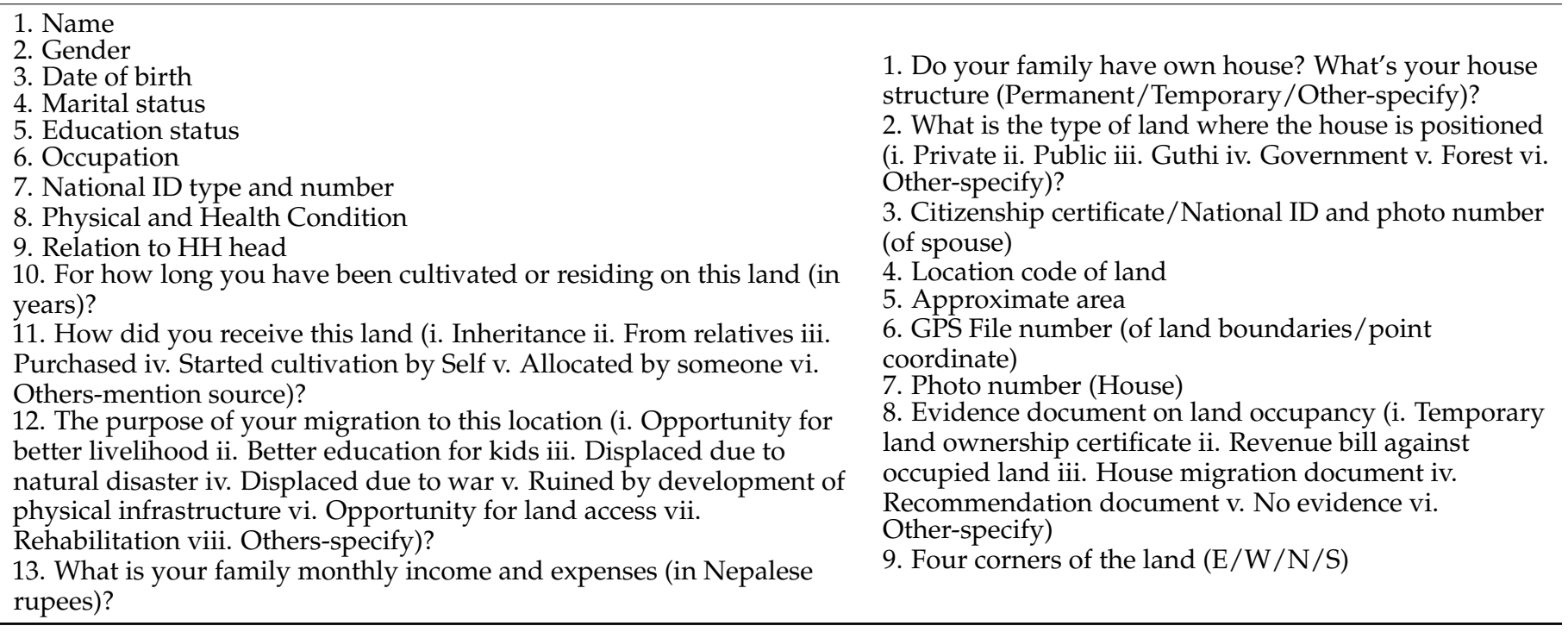




\section{References}

1. Joshi, J.R.; Panday, U.S.; Chhatkuli, R.R.; Enemark, S.; Antonio, D.; Deuja, J.; Sylla, O. Fit-For-Purpose Land Administration Strategy: An Innovative Approach to Implement Land Policies in Nepal. In Proceedings of the Land and Poverty Conference 2019: Catalyzing Innovation, Washington, DC, USA, 25-29 March 2019; p. 25.

2. MOALMC; GLTN; UNHABITAT; CSRC. Fit-For-Purpose Land Administration: A Country Level Implementation Strategy for Nepal. 2018. Available online: https://gltn.net/download/full-report-fit-for-purpose-land-administration-a-country-levelimplementation-strategy-for-nepal/?wpdmdl=12829\&ind=0 (accessed on 2 July 2021).

3. Panday, U.S.; Joshi, J.R.; Chhatkuli, R.R.; Enemark, S.; Antonio, D.; Deuja, J. Development of Fit-For-Purpose Land Administration Country Strategy: Experience from Nepal. In Proceedings of the FIG Working Week 2019, Hanoi, Vietnam, 22-26 April 2019 ; p. 15.

4. Cox, T. Land Rights and Ethnic Conflict in Nepal. Econ. Polit. Wkly. 1990, 25, 1318-1320.

5. Sapkota, M. Public land movement in Nepal: Expanding coverage and diminishing achievements. Nepal J. Soc. Sci. Public Policy 2016, 4, 19.

6. Tamang, M. Accord-An International Review of Peace Initiatives; Conciliation Resources: London, UK, 2017 ; p. 10.

7. The Asia Foundation. The State of Conflict and Violence in Asia; The Asia Foundation: San Francisco, CA, USA, 2017.

8. Upreti, B.R. Nepal's Armed Conflict: Security Implications for Development and Resource Governance; The International Centre for Integrated Mountain Development: Kathmandu, Nepal, 2006.

9. Macours, K. Increasing inequality and civil conflict in Nepal. Oxf. Econ. Pap. 2011, 63, 26. [CrossRef]

10. Chhatkuli, R.R.; Dhakal, S.; Antonio, D.; Singh, S. Statutory Versus Locally Existing Land Tenure Typology: A Dilemma for Good Land Governance in Nepal. In Proceedings of the FIG Working Week 2019 Geospatial Information for A Smarter Life and Environmental Resilience, Hanoi, Vietnam, 22-26 April 2019; p. 10.

11. Wily, L.A.; Chapagain, D.; Sharma, S. Land Reform in Nepal Where Is It Coming from and Where Is It Going? The Findings of a Scoping Study on Land Reform for DFID Nepal; Tribhuvan University: Kirtipur, Nepal, 2009; ISBN 978-99937-213-90-5.

12. LIRC Preliminary Data Collected by Land Issues Resolving Commission (LIRC); LIRC: Kathmandu, Nepal, 2020.

13. AI-Nepal; CSRC; JURI-Nepal. Nepal: Land for Landless Peasants-Comments and Recommendations on Amendment to the Lands Act 1964; Amnesty International Nepal: Kathmandu, Nepal, 2019. Available online: https://www.amnesty.org/download/Documents/ ASA3112212019ENGLISH.pdf (accessed on 14 July 2021).

14. Adhikari, J. Land Reform in Nepal: Problems and Prospects; Nepal Institute of Development Studies: Kathmandu, Nepal, 2008 ; p. 162.

15. Government of Nepal. The Lands Act, 2021 (1964 BS); Nepal Law Commission: Kathmandu, Nepal, 1964.

16. CSRC. Locally Present Land Tenure Typology in Nepal: A Study Report; GLTN Publications: Kathmandu, Nepal, 2018.

17. United People's Front Nepal Translation of 40 Point Demand to the Prime Minister of Nepal by the United People's Front; Nepal, 1996. Available online: https://www.satp.org/satporgtp/countries/nepal/document/papers/40points.htm (accessed on 2 July 2021).

18. Government of Nepal Comprehensive Peace Agreement between the Government of Nepal and the Communist Party of Nepal (Maoist); 2006; p. 13. Available online: https:// peacemaker.un.org/nepal-comprehensiveagreement2006 (accessed on 14 July 2021).

19. Government of Nepal. The Constitution of Nepal, 2015 (2072 BS); Nepal Law Commission: Kathmandu, Nepal, 2015.

20. Government of Nepal. Local Government Operation Act, 2017 (2074 BS); Nepal Law Commission: Kathmandu, Nepal, 2017 ; p. 86.

21. World Bank Land. Available online: https://www.worldbank.org/en/topic/land (accessed on 23 November 2020).

22. Aditya, T.; Unger, E.-M.; vd Berg, C.; Bennett, R.; Saers, P.; Syahid, H.L.; Erwan, D.; Wits, T.; Widjajanti, N.; Santosa, P.B.; et al. Participatory land administration in Indonesia: Quality and usability assessment. Land 2020, 9, 79. [CrossRef]

23. Enemark, S.; Mclaren, R.; Lemmen, C. Fit-For-Purpose Land Administration: Guiding Principles for Country Implementation; United Nations Human Settlements Programme: Nairobi, Kenya, 2016.

24. UNGGIM. Framework for Effective Land Administration: A Reference for Developing, Reforming, Renewing, Strengthening, Modernizing and Monitoring Land Administration; UNGGIM: New York, NY, USA, 2020. Available online: https://ggim.un.org/meetings/ GGIM-committee/10th-Session/documents/E-C.20-2020-29-Add_2-Framework-for-Effective-Land-Administration.pdf (accessed on 14 July 2021).

25. Unger, E.-M.; Chhatkuli, R.R. Fit-For-Purpose Land Administration in a Post Disaster Context: Lessons and Applications from Nepal; United Nations Human Settlements Programme: Nairobi, Kenya, 2019.

26. Unger, E.M.; Chhatkuli, R.R.; Antonio, D.; Lemmen, C.H.J.; Zevenbergen, J.A.; Bennett, R.M.; Dijkstra, P. Creating Resilience to Natural Disasters through FFP Land Administration-An Application in Nepal. In Proceedings of the 20th Annual World Bank Conference on Land and Poverty 2019: Catalyzing Innovation, Washington, DC, USA, 25-29 March 2019; p. 20.

27. Dijkstra, P.; Antonio, D.; Chhatkuli, R.R.; Beshah, W.T.; Shrestha, S.S.; Lemmen, C. Implementation of Fit for Purpose Land Administration Approaches in Nepal. In Proceedings of the FIG Congress 2018: Embracing Our Smart World Where the Continents Connect-Enhancing Geospatial Maturity of Societies, Istanbul, Turkey, 6-11 May 2018.

28. SILTIP; HURADEC-Nepal. Support for Land Reform in Nepal and Land Tenure Initiative in Asia-Pacific; Charikot: Dolakha, Nepal, 2017.

29. Giri, H. An Exploration of Ethnic Dynamics in Nepal. J. Popul. Dev. 2020, 1, 71-78. [CrossRef]

30. MOFA Nepal Profile. Available online: https://mofa.gov.np/about-nepal/nepal-profile/ (accessed on 10 May 2021).

31. Leitner Center for International Law and Justice. Land Is Life, Land Is Power: Landlessness, Exclusion, and Deprivation in Nepal; Leitner Center for International Law and Justice: New York, NY, USA, 2011.

32. Höfer, A. The Caste Hierarchy and the State in Nepal: A Study of the Muluki Ain of 1854, 2nd ed.; Himal Books: Kathmandu, Nepal, 2004; ISBN 9789993343585. 
33. Macalester College. Constitution of the Kingdom of Nepal VS 2047 (1990). Himalaya J. Assoc. Nepal Himal. Stud. 1991, 11, 51.

34. GoN. The Interim Constitution of Nepal 2007 (2063 BS); 2007; p. 167. Available online: http://www.ilo.org/wcmsp5/groups/ public/---ed_protect/---protrav/---ilo_aids/documents/legaldocument/wcms_126113.pdf (accessed on 14 July 2021).

35. GoN. The Constitution of Nepal, 2015 (2072 BS); 2015; p. 240. Available online: https://www.mohp.gov.np/downloads/ Constitution\%20of\%20Nepal\%202072_full_english.pdf (accessed on 14 July 2021).

36. NPC. The Fifteenth Plan (Fiscal Year 2019/20-2023/24); The National Planning Commission: Kathmandu, Nepal, 2020.

37. NPC; UNDP. Beyond Graduation: Productive Transformation and Prosperity; UNDP: Kathmandu, Nepal, 2020.

38. MOAD. Agriculture Development Strategy (ADS) 2015 to 2035; Ministry of Agricultural Development: Kathmandu, Nepal, 2015.

39. Aryal, J.P.; Holden, S.T. Land reforms, caste discrimination and land market performance in Nepal. In Land Tenure Reform in Asia and Africa; Holden, S.T., Otsuka, K.D.K., Eds.; Palgrave Macmillan, London: London, UK, 2013; pp. 29-53. ISBN 978-1-349-46586-6.

40. IOM. Barriers to Women's Land and Property Access and Ownership in Nepal; International Organization for Migration (IOM): Kathmandu, Nepal, 2016. Available online: https:/ /www.iom.int/sites/default/files/our_work/DOE/LPR/Barriers-to-WomensLand-Property-Access-Ownership-in-Nepal.pdf (accessed on 14 July 2021).

41. FAO. Country Gender Assessment of Agriculture and the Rural Sector in Nepal; Food and Agriculture Organization of the United Nations: Kathmandu, Nepal, 2019. Available online: http:/ / www.fao.org/3/CA3128EN/ca3128en.pdf (accessed on 14 July 2021).

42. MoLMCPA National Land Policy; The Ministry of Land Management, Cooperatives and Poverty Alleviation (MoLMCPA): Kathmandu, Nepal, 2019; p. 24. Available online: https://molcpa.gov.np/storage/uploads/land\%20use\%20policy_2015_ ENGLISH_1514355245_1542355707.pdf (accessed on 2 July 2021).

43. Unger, E.-M.; Bennett, R. Fit-For-Purpose Land Administration for All: A Guide for Surveyors on Adoption and Adaptation of Fit-ForPurpose Land Administration; United Nations Human Settlements Programme: Nairobi, Kenya, 2019.

44. Baldwin, R.; English, C.; Lemmen, C.; Rose, I.; Smith, A.; Solovov, A.; Sullivan, T. Are Local Registers the Solution? In Proceedings of the 19th Annual World Bank Conference on Land and Poverty, Washington, DC, USA, 19-23 March 2018; p. 27.

45. Enemark, S.; Bell, K.C.; Lemmen, C.; McLaren, R. Fit-For-Purpose Land Administration; FIG Publication: Copenhagen, Denmark, 2014.

46. Rajdevi Engineering Consultant. Carrying Out Study on Comparison of Various Cadastral Data Acquisition Technology; Rajdevi Engineering Consultant (P) Ltd.: Kathmandu, Nepal, 2016.

47. Coughlan, P.; Coghlan, D. Action Research: Action Research for Operations Management. Int. J. Oper. Prod. Manag. 2002, 22, 220-240. [CrossRef]

48. Apollo Mapping PLÉIADES 1. Available online: https://apollomapping.com/pleiades-1-satellite-imagery (accessed on 1 April 2021).

49. FAO. Voluntary Guidelines on the Responsible Governance of Tenure of Land, Fisheries and Forests in the Context of National Food Security; Food and Agriculture Organization: Rome, Italy, 2012.

50. Government of Nepal. The 8th Amendment to the Land Act 1964; The Ministry of Law, Justice and Parliametry Affairs: Kathmandu, Nepal, 2020; p. 16.

51. Government of Nepal. The 18th Amendment of the Land Regulations. Available online: http://lirc.gov.np/storage/uploads/-1 881417450.pdf (accessed on 2 July 2021).

52. Ho, S.; Choudhury, P.R.; Haran, N.; Leshinsky, R. Decentralization as a Strategy to Scale Fit-for-Purpose Land Administration: An Indian Perspective on Institutional Challenges. Land 2021, 10, 199. [CrossRef]

53. Mint How Many Indians are landless? Available online: https://www.livemint.com/Opinion/PUzqHSs3xejXk4hm2djTPM/ How-many-Indians-are-landless.html (accessed on 12 May 2021).

54. Merry, K.; Bettinger, P. Smartphone GPS accuracy study in an urban environment. PLoS ONE 2019, 14, e0219890. [CrossRef] [PubMed]

55. Chio, S.H.; Chiang, C.C. Feasibility study using UAV aerial photogrammetry for a boundary verification survey of a digitalized cadastral area in an Urban City of Taiwan. Remote Sens. 2020,12, 1682. [CrossRef]

56. Hackman-Antwi, R.; Bennett, R.M.; de Vries, W.T.; Lemmen, C.H.J.; Meijer, C. The point cadastre requirement revisited. Surv. Rev. 2013, 45, 239-247. [CrossRef]

57. USGS. USGS Global Positioning Application and Practice. Available online: https://water.usgs.gov/osw/gps/ (accessed on 1 April 2021).

58. Yagol, P.; Shrestha, E.; Thapa, L.; Poudel, M.; Bhatta, G.P. Comparative Study on Cadastral Surveying Ising Total Station and High Resolution Satellite Image. In Proceedings of the FIG-ISRPS, 2015: International Workshop on Role of Land Professionals and SDI in Disaster Risk Reduction: In the Context of Post 2015 Nepal Earthquake, Kathmandu, Nepal, 25-27 November 2015 ; p. 10.

59. Kohli, D.; Unger, E.; Lemmen, C. Validation of A Cadastral Map Created Using Satellite Imagery and Automated Feature Extraction Techniques: A Case of Nepal. In Proceedings of the FIG Congress 2018: Embracing Our Smart World Where the Continents Connect: Enhancing the Geospatial Maturity of Societies, Istanbul, Turkey, 6-11 May 2018; p. 12.

60. Koirala, M.P. Provided Cadastral Survey Maps Commencing Risks to Identifying and Valuing the Land in Nepal. World J. Eng. Res. Technol. 2019, 5, 263-273.

61. Vuksanović-Macura, Z. The mapping and enumeration of informal Roma settlements in Serbia. Environ. Urban. 2012, 24, 685-705. [CrossRef] 
62. Bennett, R.M.; Alemie, B.K. Fit-for-purpose land administration: Lessons from urban and rural Ethiopia. Surv. Rev. 2016, 48, 11-20. [CrossRef]

63. Balas, M.; Carrilho, J.; Joaquim, S.; Murta, J.; Lemmen, C.; Matlava, L.; Marques, M.R. Mozambique Participatory Fit for Purpose Massive Land Registration. In Proceedings of the Responsible Land Governance: Towards and Evidence Based Approach, Annual World Bank Conference on Land and Poverty, Washington, DC, USA, 20-24 March 2017.

64. GoN. Formation Order: Land Issues Resolving Commission (in Nepali Language); Nepal Law Commission: Kathmandu, Nepal, 2020; p. 22. 